\title{
Dynamic Neurotransmitter Interactions Measured with PET
}

\author{
Wynne K. Schiffer ${ }^{\dagger \ddagger} \&$ Stephen L. Dewey ${ }^{\dagger \dagger}$
}

†NYU School of Medicine, Department of Psychiatry, New York, NY 10016

*Brookhaven National Laboratory, Chemistry Department, Upton NY 10016 


\section{INTRODUCTION}

Positron emission tomography (PET) has become a valuable interdisciplinary tool for understanding physiological, biochemical and pharmacological functions at a molecular level in living humans, whether in a healthy or diseased state. The utility of tracing chemical activity through the body transcends the fields of cardiology, oncology, neurology and psychiatry. In this, PET techniques span radiochemistry and radiopharmaceutical development to instrumentation, image analysis, anatomy and modeling. PET has made substantial contributions in each of these fields by providing a venue for mapping dynamic functions of healthy and unhealthy human anatomy.

As diverse as the disciplines it bridges, PET has provided insight into an equally significant variety of psychiatric disorders. Using the unique quantitative ability of PET, researchers are now better able to non-invasively characterize normally occurring neurotransmitter interactions in the brain. With the knowledge that these interactions provide the fundamental basis for brain response, many investigators have recently focused their efforts on an examination of the communication between these chemicals in both healthy volunteers and individuals suffering from diseases classically defined as neurotransmitter specific in nature. In addition, PET can measure the biochemical dynamics of acute and sustained drug abuse. Thus, PET studies of neurotransmitter interactions enable investigators to describe a multitude of specific functional interactions in the human brain. This information can then be applied to understanding side effects that occur in response to acute and chronic drug therapy, and to designing new drugs that target multiple systems as opposed to single receptor types. Knowledge derived from PET studies can be applied to drug discovery, research and development (for review, see (Fowler et al., 1999) and (Burns et al., 1999)).

Here, we will cover the most substantial contributions of PET to understanding biologically distinct neurochemical systems that interact to produce a variety of behaviors and disorders. Neurotransmitters are neither static nor isolated in their distribution. In fact, it is through interactions with other neurochemically distinct systems that the central nervous system (CNS) performs its vital role in sustaining life. Exclusive quantitative capabilities intrinsic to PET make this technology a suitable experimental tool to measure not only the regional distribution of specific receptors and their subtypes, but also the dynamic properties of neuroreceptors and their inherent influence on related neurotransmitter pathways. The ability to 
investigate dynamic properties in a non-invasive and reproducible manner provides a powerful tool that can extend our current knowledge of these interactions. Coupled with innovative paradigms including pharmacologic manipulations, physiologic models and reconstruction theories, knowledge derived from PET studies can greatly advance our understanding of normal and abnormal brain function.

\section{TECHNICAL ATTRIBUTES SPECIFIC TO NEUROTRANSMITTER MAPPING WITH PET}

Neurotransmitter mapping with PET is based on the principle that labeled compounds can be designed to compete with endogenous neurochemical activity at receptor sites on both preand post-synaptic terminals. In this, radiotracers can be targeted at a number of physiological functions, from pre-synaptic release and reuptake to post-synaptic uptake. In the midst of disease states, this information provides vital insight into the development of potential pharmacologic interventions (Ding et al., 1995; Ginovart et al., 1997; Frey et al., 1996; Meyer et al., 1999). Further, neurochemical mapping with PET can be carefully controlled, so that depending on the kinetic properties of the tracer molecule, varying degrees of competition interfere with normal neurotransmitter activity and occupy all receptor sites, or less competitively occupy only a few of the receptor sites. Several concepts are fundamental to understanding the general foundation of mapping dynamic neurochemical interactions with PET. These are the choice of a ligand and target neurotransmitter system, kinetic modeling of chosen radioligands, and specific to multi-neurotransmitter investigations, the design of a challenge paradigm. From this, we can assay the effects of pharmaceuticals on interrelated neurotransmitter systems as well as gather information about regular and irregular endogenous states.

\section{The Ligand}

The freedom implied by the ability to label a variety of compounds might lead one to raise the possibility of labeling the neurotransmitters themselves, but this is impossible for several reasons. Primarily, neurotransmitters do not cross the blood-brain barrier. Because labeled compounds must be injected or inhaled, blood-brain barrier permeability is necessary. 
Second, the binding affinity of all amino acid and amine neurotransmitters to their specific receptors is low. In this, the fate of neurotransmitters themselves cannot be controlled (i.e. presynaptic reuptake or enzymatic degredation), but the action of a molecule designed to bind to a specific receptor, or ligand, can be reliably predicted depending on the kinetics of the labeled molecule. Therefore, it is necessary to use molecules that bind to the receptor under investigation with a known affinity.

The choice of a ligand should be clinically relevant, and its actions should be well documented. In this, ligands should have a known affinity for specific receptor subtypes to minimize the possibility of confounding effects or untraceable radioligand activity from promiscuous ligand delivery. Second, ligands should have a biological half-life long enough to remain in systemic circulation for the duration of the scanning period (although kinetic modeling parameters can compensate for this). Finally, it is important that ligands have a conformation that can be readily labeled while retaining blood-brain barrier permeability.

By using a competitive ligand with a high affinity, the amount of neurotransmitter bound to receptor sites will be insignificant compared with the amount of ligand bound to identical sites. Theoretically, noncompetitive ligands with moderate affinity do not interfere with endogenous neurotransmitter activity (Seeman et al., 1990). Investigations that use competitive ligands identify fundamental neuroreceptor arrangement, and typically differentiate basal receptor physiology in healthy and unhealthy psychiatric conditions. For example, the high affinity $\mathrm{D}_{2}$ receptor radiotracer ${ }^{11} \mathrm{C}-\mathrm{N}$-methylspiroperidol $\left({ }^{11} \mathrm{C}-\mathrm{NMSP}\right)$ demonstrated a two- to three-fold increase in ligand competition in schizophrenic patients when compared to normal controls (Wong et al., 1986), while the noncompetitive $\mathrm{D}_{2}$ radiotracer ${ }^{11} \mathrm{C}$-raclopride demonstrated no change in competition between schizophrenic patients and controls (Farde et al., 1987). A later discovery was that endogenous dopamine (DA) released into the synapse competes with ${ }^{11} \mathrm{C}$-raclopride for $\mathrm{D}_{2}$ receptor binding sites (Seeman et al., 1990), whereas ${ }^{11} \mathrm{C}$ NMSP is less sensitive to the influence of endogenous dopamine (Logan et al., 1992) and possibly a more effective tool for measuring receptor physiology. Further, while Farde et al., demonstrated no change in the binding characteristics of ${ }^{11} \mathrm{C}$-raclopride between schizophrenic patients and normal controls, Breier et al. (1997) recently demonstrated amphetamine-induced increases in dopamine release produce less ${ }^{11} \mathrm{C}$-raclopride binding in schizophrenic patients when compared to healthy controls given the same challenge (Breier et al., 1997). Together, 
these studies support the existence of similar endogenous dopamine activity between schizophrenic patients and controls, while demonstrating substantially different responses to a challenge of the dopamine system. In this, measurement of dynamic neurotransmitter activity may be more informative about the plasticity of neurochemical activity in the brain than about a single physiological trait like receptor concentration.

\section{Kinetic Modeling}

The scientific progression from investigations of static neuroreceptor concentration to dynamic neurotransmitter activity also instigated marked innovations in the methods by which we process and statistically manipulate data from PET cameras. Specifically, the initial receptor mapping studies by Wong (Wong et al., 1986) and Farde (Farde et al., 1987) used the same radioactive label on two compounds with different pharmacokinetic properties. ${ }^{11} \mathrm{C}$-raclopride, used by Farde et al., reaches equilibrium during the time of the scan and allows the quantification of binding parameters via a Scatchard plot. ${ }^{11} \mathrm{C}-\mathrm{NMSP}$, however, does not reach equilibrium within the period of the scan and requires kinetic modeling (Tune et al., 1993). It is now possible to estimate changes in endogenous dopamine following a pharmacologic challenge in each PET study with a mathematical approach (for example, see (Dewey et al., 1992a)). Since extracting absolute measures of neurotransmitter concentrations requires knowledge of both receptor concentration $\left(\mathrm{B}_{\max }\right)$ and the in vivo receptor-ligand dissociation constant, $\mathrm{k}_{\mathrm{d}}$, and estimations of $\mathrm{B}_{\max }$ are crude and difficult to measure (Logan et al., 1997), results from most dynamic PET studies are expressed as relative change between baseline (radiotracer alone) and challenge scans (i.e. pretreatment + challenge drug + radiotracer). Studies in our laboratory were designed to examine changes in receptor availability by determining parameters that are linearly related to free receptors, rather than the actual number of free receptors targeted by conventional neuroreceptor investigations.

For noncompetitive, moderate affinity radiotracers, two such modeling parameters are the distribution volume (DV) and $\mathrm{B}_{\max } / \mathrm{K}_{\mathrm{d}}$. The distribution volume is a graphical method of analysis applied to ligands that bind reversibly to receptors or enzymes. A method for determining DV was developed for the kinetic analysis of ${ }^{11} \mathrm{C}$-cocaine data and has been applied to the analysis of ${ }^{11} \mathrm{C}$-benztropine and ${ }^{11} \mathrm{C}$-raclopride data used in our investigations of neurotransmitter activity (Logan et al., 1990); (Dewey et al., 1990c). Alternatively, the DV can 
also be calculated from the kinetic parameters determined from a non-linear least squares fit of the data using a compartmental model. For a three compartment model, the steady state DV $\left(\mathrm{K}_{\mathrm{R}}\right)$ is given by $\mathrm{K}_{1} / \mathrm{k}_{2}\left(1+\mathrm{k}_{3} / \mathrm{k}_{4}\right)$. For a two compartment model, the ratio $K_{R}$ is expressed by $K_{1} / k_{2}$. For the analysis of ${ }^{11} \mathrm{C}$-cocaine data, kinetic parameters determined using the graphical technique are consistent with estimates from a nonlinear least squares method. In addition, the ratio $\mathrm{B}_{\max } / \mathrm{K}_{\mathrm{d}}$ is similar to that found in vitro (Logan et al., 1990).

One of the advantages of applying the DV approach is that it represents a linear function of free receptor concentration and does not depend on blood flow, since the variables containing blood flow cancel in the ratio $\mathrm{K}_{1} / \mathrm{k}_{2}$. Specifically, if we calculate the ratio of the $\mathrm{DV}$ for a region containing few or no target receptors to the $\mathrm{DV}$ for a receptor-rich region, the $\mathrm{K}_{1} / \mathrm{k}_{2}$ ratio can be eliminated, giving a parameter more closely related to $\mathrm{B}_{\max } / \mathrm{K}_{\mathrm{d}}$. As a validation of the $\mathrm{DV}$ ratio approach, Koeppe et al., (Koeppe et al., 1991) established that focal alterations in blood flow produced by visual stimulation coincided with a $21 \%$ increase in ligand delivery $\left(\mathrm{K}_{1}\right)$ to the visual cortex. In this investigation, the DV for ${ }^{11} \mathrm{C}$-flumazenil in the visual cortex or other regions was unaltered, supporting the insensitivity of the DV parameter to focal alterations in blood flow. The DV parameter is also easily computed and less sensitive to noise than the individual kinetic parameters, which often have large standard errors associated with their determination. This technique is conceptually similar to the two-compartment model approach used by Frey et al., (Frey et al., 1990) to study muscarinic receptors with ${ }^{11} \mathrm{C}$-tropanyl benzilate and by Koeppe et al., (Koeppe et al., 1991) to study benzodiazepine receptors with ${ }^{11} \mathrm{C}$ flumazenil. In sum, our investigations estimate the free concentration of tracer in tissue and the concentration of nonspecifically bound tracer from a reference region of the brain that contains few or no target receptors. For ${ }^{11} \mathrm{C}$-raclopride and ${ }^{11} \mathrm{C}$-benztropine, the cerebellum provides a reference region containing few or no dopamine or cholinergic terminals or receptors, so ligands for these receptors distribute only to the compartments of free ligand and nonspecifically bound ligand. Data from PET studies reported here is expressed as the percentage change relative to the baseline DV ratio of radiotracer binding.

NEUROTRANSMITTER INTERACTIONS MEASURED WITH PET 
Neurodevelopmental models support the involvement of large numbers of discrete neurons involved in adaptive plasticity, and contend that these processes underlie psychopathology (Olney and Farber, 1995). It is also likely, however, that many diverse neurotransmitter systems contribute to maintain a certain level of homeostasis. Whether a healthy or unhealthy state, there remains a dynamic interplay between endogenous systems to sustain the organism.

Noncompetitive receptor ligands have been established as successful markers of endogenous neurotransmitter activity, and are sensitive to pharmacologic challenges that either increase or decrease synaptic concentrations of the target neurotransmitter. Our laboratory and others have taken this paradigm one step further to explore the functional interactions between isolated neurotransmitter systems. To do this, we measured the acute response of one neurotransmitter system to a challenge targeting a discrete, related system. Prior to evaluating the feasibility of PET as an accurate measure of simultaneous neurotransmitter interactions, it was essential to select for study a well-defined neurotransmitter system whose function is dependent on interactions between at least two chemically different neurotransmitter systems. Furthermore, the target system should be particularly sensitive to alterations in either of these endogenous neurotransmitters and their site of interaction must be localized to neurochemical factors that are within the resolution of the machine itself. Within the confines of these requirements, the extra-pyramidal motor system provides a multi-neurotransmitter region within the window of PET resolution.

Interconnections of the extra-pyramidal motor system have been extensively documented in animal and human postmortem studies using a wide variety of neuroanatomical, neurophysiological and behavioral methods. The principle components of this system involve interactions between acetylcholine, dopamine, gamma aminobutyric acid (GABA) and serotonin. Disruptions in any single component of this system present a discrete clinical picture. For example, therapeutically relevant blockade of dopamine $\mathrm{D}_{2}$ receptors produces movement disorders, which can be alleviated by decreasing cholinergic activity. Studies using a variety of methods have demonstrated that these neurochemical systems interact in the corpus striatum through reciprocal inhibitory and excitatory connections with the substantia nigra and medial raphe nucleus (Arnfred and Randrup, 1968; Bloom et al., 1965; Costall and Olley, 1971; Ehlert et al., 1981; Lehmann and Langer, 1982). The corpus striatum, consisting of the caudate nucleus 
and putamen, is well within the resolution of modern PET scanners and contains a large number of dopamine $\mathrm{D}_{2}$ and cholinergic muscarinic receptors. While each of these neurotransmitters is involved in maintaining the necessary input required for the normal day-to- day operation of the extra-pyramidal motor system, each has been implicated in other physiological roles that may or may not be directly linked to the neuronal systems mentioned above. These other roles may contribute to disease states of the CNS and/or conditions that predispose or maintain drug addiction.

\section{Modulation of dopaminergic activity studied with ${ }^{11} \mathrm{C}$-raclopride and ${ }^{18}$ F-NMSP}

The interpretation of neurotransmitter interaction studies is dependent on the ability of each radiotracer to demonstrate receptor specific binding and reproducibility, and also on the ability of each radiotracer to reflect fluctuations in receptor availability secondary to druginduced changes in endogenous neurotransmitter activity. Therefore, in a series of PET studies, we utilized a multi-mechanistic approach to investigate the effects of increases in endogenous dopamine on the binding of ${ }^{11} \mathrm{C}$-raclopride. Using $d$-amphetamine and GBR-12909, drugs that alter synaptic dopamine concentrations by different mechanism.s, we addressed the question of whether ${ }^{11} \mathrm{C}$-raclopride binding is sensitive to changes in endogenous dopamine. In the first set of studies, we used $d$-amphetamine to increase synaptic dopamine levels by releasing cytostolic stores into the synapse. Following $d$-amphetamine administration, the ratio of striatal to cerebellar DV for ${ }^{11} \mathrm{C}$-raclopride decreased by an average of $16 \%$. Parallel studies using in vivo microdialysis techniques in freely moving rats demonstrate $d$-amphetamine significantly increases extracellular striatal DA release. GBR-12909, a potent dopamine reuptake inhibitor, decreased the same ratio by an average of $22 \%$. Again, this investigation was confirmed by microdialysis studies indicating an increase in extracellular dopamine release following GBR12909 pretreatment (Dewey et al., 1993b). Together, these studies demonstrated that our system was capable of measuring changes in synaptic dopamine concentrations, and prompted the utility of this strategy to quantify changes in dopamine activity secondary to pharmacologic modulation of related, upstream neurotransmitter systems. For a summary of each investigation and the result, please see Table 1. 


\section{Cholinergic modulation of dopamine}

Initially, our investigations of dynamic neurochemical interactions measured with PET looked at the cholinergic/dopaminergic system, with the outcome measure being changes in endogenous dopamine activity. The cholinergic system has demonstrated an essential role in many memory and cognitive functions (Davies and Verth, 1977; Meltzer and Stahl, 1976). Some studies have hypothesized that cholinergic hyperactivity may underlie the negative symptoms associated with schizophrenic illnesses as well (Tandon and Greden, 1989). The highest levels of choline acetyltransferase and cholinergic receptors in the human CNS are found in the striatum and the majority of cholinergic cells are interneurons (Cortes et al., 1987; Fibiger, 1982). These cholinergic interneurons provide excitatory input to local GABA neurons, which in turn are thought to inhibit the activity of dopaminergic neurons (Bunney and Aghajanian, 1976).

Our initial primate investigations demonstrated the binding of ${ }^{18} \mathrm{~F}$-NMSP was reduced by $13 \%$ after the animals received an injection of benztropine (an anticholinergic agent) when compared to control animals receiving no benztropine (Dewey et al., 1990a). This result was confirmed in human subjects where the uptake of ${ }^{18} \mathrm{~F}-\mathrm{NMSP}$ in the striatum was reduced by an average of $10 \%$ after benztropine pretreatment (Dewey et al., 1988) ${ }^{1}$. In a related study, we used

${ }^{11} \mathrm{C}$-raclopride as the radiotracer and scopolamine as the cholinergic challenge drug, as it has a more selective mechanism of action than benztropine. Human subjects treated with scopolamine demonstrated a decrease in striatal ${ }^{11} \mathrm{C}$-raclopride binding of $17 \%$, indicating greater increases in endogenous dopamine competition after scopolamine when compared to benztropine (Dewey et al., 1993c).

In sum, decreased brain acetylcholine levels secondary to benztropine or scopolamine treatment appear to increase brain dopamine, indicated by decreased ${ }^{18} F-N M S P$ binding.

These data are consistent with the aforementioned model of a multisynaptic feedback loop linking cholinergic neurons indirectly to dopaminergic neurons via GABAergic interneurons (Bunney and Aghajanian, 1976). By decreasing cholinergic activity, benztropine inhibits the excitatory input to GABAergic neurons, reducing GABAergic inhibition of dopaminergic neurons. Subsequent disinhibition of dopaminergic neurons produces a higher level of synaptic dopamine release, and increased competition with ${ }^{11} \mathrm{C}$-raclopride at 
postsynaptic $\mathrm{D}_{2}$ receptors. These studies demonstrate that in some circumstances, acetylcholine regulates brain dopamine release.

\section{Serotonergic modulation of dopamine}

Further studies investigating the modulation of dopaminergic systems focused on the possible modulation of dopamine by serotonin, as interactions between these systems have been well documented. Functionally, serotonin has been implicated in sleep, aggression, pain transmission, Alzheimer's disease, normal aging, affective disorders and suicide (Wesemann et al., 1983; Stanley and Mann, 1984; Pucilowski and Kostowski, 1983; Bowen et al., 1983; Crow et al., 1984; Middlemiss et al., 1986; Reynolds et al., 1984). In addition, the greater affinity of several atypical neuroleptics, non-benzodiazepine anxiolitics and new antidepressant agents (e.g., selective serotonin reuptake inhibitors, SSRIs) for cortical serotonin receptors has been linked to their therapeutic efficacy. Electrophysiological, biochemical and behavioral evidence indicates ascending serotonergic pathways from the medial and dorsal raphe modulate the function of mesolimbic and mesostriatal dopamine systems (Joyce et al., 1993; Joyce, 1993; Zazpe et al., 1994); (Kapur and Remington, 1996). Our initial primate studies used the 5-HT receptor antagonist altanserin as a pretreatment drug found that ${ }^{11} \mathrm{C}$-raclopride binding was reduced by $37 \%$ in the striatum (Dewey et al., 1995), indicating diminished 5-HT activity actually stimulated dopamine release. In the same study, increasing 5-HT activity with citalopram (SSRI) decreased synaptic dopamine levels and increased striatal ${ }^{11}$ C-raclopride binding. These studies were later confirmed by Tsukada et al., who decreased 5-HT with ketanserine (similar to altanserin) and found decreased ${ }^{11} \mathrm{C}$-raclopride binding in the striatum, consistent with increased dopamine release (Tsukada et al., 1999).

By decreasing serotonergic activity with altanserin, we quantified secondary increases in brain dopamine by measuring decreases in ${ }^{11}$ C-raclopride binding (indicating increased competition from endogenous dopamine). Next, we increased serotonergic activity with citalopram administration and demonstrated decreases in endogenous dopamine release with increased ${ }^{11}$ C-raclopride binding.

In an attempt to extend this finding to human subjects, we used fenfluramine, a selective 5-HT reuptake inhibitor and releasing agent, to increase serotonergic activity (Smith et al., 1997). Our results, contrary to our previous findings in baboons, indicated that increasing 5-HT 
activity increased DA activity, as evidenced by a $13 \%$ decrease in ${ }^{11} \mathrm{C}$-raclopride binding. These results are consistent with more recent studies indicating chronic (Tiihonen et al., 1996) or acute (Vollenweider et al., 1999) increases in serotonergic transmission produced increases in synaptic dopamine concentrations, as evidenced by PET and ${ }^{11} \mathrm{C}$-raclopride binding. The difference between our primate and human results may be due to the broad serotonergic effect of fenfluramine versus altanserin, the effects of anesthesia on the baboon, or species-specific effects.

Increasing serotonergic activity with fenfluramine produced subsequent increases in serotonergic activity measured by decreased ${ }^{11} C$-raclopride binding.

\section{GABAergic modulation of dopamine}

We have also used the pharmacological challenge paradigm with PET to study the GABA/dopamine interaction. The finding that GABA functions as the most common inhibitory neurotransmitter in the CNS resulted in its implication, either directly or indirectly, in the pathogenesis of several neurodegenerative conditions. These conditions include Huntington's and Parkinson's Disease, epilepsy, schizophrenia and tardive dyskinesias. In addition, studies have shown that GABAergic activity modulates central neurotransmitter systems targeted by drugs of addiction (DeFeudis, 1984; Koob, 2000; Dewey et al., 1998). Thus, numerous PET studies have been aimed at the study of GABAergic systems and their contributions to disease and addictive states. There are several inherent difficulties in perturbing the GABA receptor complex, including the controversy over the GABA receptor subtypes and their functional role in the striatum. The availability of specific GABA receptor agonists or antagonists that reliably affect central GABA levels without producing profound disruptions in CNS function has also been a concern. The administration of gamma-vinyl GABA (GVG, vigabatrin), a suicide inhibitor of the GABA catabolizing enzyme GABA transaminase, has been used to successfully enhance GABAergic neurotransmission through increased brain GABA levels. This compound is used clinically to treat epilepsy, and it has been shown to reliably elevate endogenous GABA levels after systemic administration without affecting other amino acid transmitters.

According to the multisynaptic feedback loop described, we would expect an inhibitory influence of GABA on the activity of dopaminergic neurons and hence an increase in ${ }^{11} \mathrm{C}$ raclopride binding. To test this, ${ }^{11} \mathrm{C}$-raclopride in baboons was imaged prior to and following the 
administration of GVG (Dewey et al., 1992a). The result was an average increase of $25 \%$ in ${ }^{11} \mathrm{C}$ raclopride binding, indicating significantly depressed synaptic DA activity. In the second part of the study, lorazepam, a clinically prescribed benzodiazepine administered intravenously prior to the scan, led to an average increase of $22 \%$ in striatal ${ }^{11} \mathrm{C}$-raclopride binding. This PET study provided evidence that dopaminergic neurons of the substantia nigra and the ventral tegmental area are responsive to pharmacological alterations in GABA activity. Interestingly, a similar investigation by Hietala et al., (Hietala et al., 1997) found weeklong pretreatment with lorazepam had no effect on striatal ${ }^{\mathrm{II}} \mathrm{C}$-raclopride binding in human patients, but acute lorazepam increased ${ }^{11} \mathrm{C}$-raclopride binding in primates.

In sum, increasing whole brain GABA levels with vigabatrin produced subsequent decreases in dopamine release, as measured by increases in ${ }^{11} C$-raclopride binding.

\section{GABAergic modulation of dopamine in substance abuse}

We have also used ${ }^{11} \mathrm{C}$-raclopride binding and PET to explore the inhibitory potential of GVG on the brain response to substances of abuse. The rewarding effects of psychostimulants have been associated with their ability to increase striatal dopamine levels (Volkow et al., 1999). The system of primary interest in these conditions involves the mesocorticolimbic dopaminergic projections from the ventral tegmental area (VTA) and substantia nigra into the ventral striatum, medial prefrontal cortex, and amygdala, which participate in the neural processing of motivated behavior (Robbins et al., 1989). Alterations in this system are thus hypothesized to play roles in mediating the euphoria and behavioral reinforcement associated with drugs of abuse (for review, see (McBride et al., 1999)). Specifically, the nucleus accumbens (NAcc) has demonstrated the greatest sensitivity to changes induced by drugs that inhibit dopamine reuptake, stimulate dopamine release, or increase dopamine through neurotransmitter system interactions. This evidence is derived from microdialysis studies in rats showing higher extracellular fluid dopamine concentrations after administration of psychostimulants (Di Chiara et al., 1993; Di Chiara et al., 1992). ${ }^{2} \quad$ In our extensive PET studies utilizing the strategy of increasing GABAergic activity with GVG as a mechanism for preventing psychostimulant induced dopamine release, we correlate striatal ${ }^{11} \mathrm{C}$-raclopride binding in primates with microdialysis investigations of NAcc dopamine release in rodents. This allows us to better relate the neural responses from various drug challenges with the many available rodent models of substance 
abuse (craving, reward and reinforcement), as well as assess the temporal window for pretreatment strategies.

Our initial studies in the substance abuse arena demonstrated that GVG restores striatal ${ }^{11} \mathrm{C}$-raclopride binding to normal levels following acute cocaine administration in baboons (Dewey et al., 1997). In other words, while a cocaine challenge diminished ${ }^{11}$ C-raclopride binding, pretreatment with GVG before cocaine produced a degree of ${ }^{11} \mathrm{C}$-raclopride binding undistinguishable from animals given ${ }^{11} \mathrm{C}$-raclopride alone. In further support of this strategy, GVG effectively modulated basal reward thresholds produced by cocaine administration (Kushner et al., 1997), abolished the conditioned place preference produced by cocaine (Dewey et al., 1998), and reduced self-administration of cocaine (Kushner et al., 1999) and heroin (Xi and Stein, 2000) in rodents. Additionally, we have demonstrated that increasing GABAergic activity with GVG can modulate decreases in ${ }^{11} \mathrm{C}$-raclopride binding produced by nicotine and heroin (Dewey et al., 1999; Gerasimov et al., 1999), consistent with microdialysis studies (Gerasimov et al., 1999).

To further investigate the specific properties of GVG that contribute to its efficacy as a potential anti-addictive agent, as well as to justify the ability of ${ }^{11} \mathrm{C}$-raclopride to detect changes induced by multiple pharmacologic manipulations, we administered the pure enantiomers of the racemic compound before an acute nicotine challenge (Schiffer et al., 2000). Our previous investigations demonstrating increases in striatal dopamine concentrations after nicotine administration served as the basis for this investigation. Where nicotine diminished ${ }^{11} \mathrm{C}$ raclopride binding by $\sim 12 \%$, pretreatment with $(R, S)-G V G$ and active $S(+)$-GVG increased ${ }^{11} \mathrm{C}$ raclopride binding 9 and $8 \%$, respectively. Figure 1 presents the radioactivity distribution of ${ }^{11} \mathrm{C}$ raclopride (red). Here, it is clear that nicotine diminishes $\mathrm{D}_{2}$ receptor occupancy (a), in that there is visibly diminished ${ }^{11} \mathrm{C}$-raclopride binding. Pretreatment with $\mathrm{S}(+)-\mathrm{GVG}$ prevents nicotineinduced dopamine release (b) and restores receptor occupancy to near test/retest values, demonstrated by increased ${ }^{11} \mathrm{C}$-raclopride binding. Additionally, pretreatment with the inactive R(-)-GVG decreased ${ }^{11}$ C-raclopride binding after a nicotine challenge by $\sim 13 \%$. These results support studies indicating that, as an anticonvulsant, the active $S(+)$ enantiomer also retains the pharmacologic efficacy of GVG. Our microdialysis data corroborate our PET studies in that $\mathrm{S}(+)-\mathrm{GVG}$ was as effective as the racemic compound at decreasing the extracellular NAcc dopamine response to cocaine in rodents. 


\section{GABAergic modulation of dopamine in schizophrenia}

The clinical potential of enhanced GABA transmission described above is most likely attributable to decreases in dopaminergic activity, believed to be a common denominator in many schizophrenic psychoses (Wassef et al., 1999). The effects of enhanced GABA function on dopaminergic pathways in the human brain are of particular interest for studies on biological factors in schizophrenia. These studies have formulated a GABA hypofunction hypothesis of schizophrenia, which postulates a deficient GABAergic inhibition in schizophrenia and subsequent alterations in other neurotransmitter systems, including DA hyperactivity in the brain (Keverne, 1999; Egan and Weinberger, 1997; Weinberger, 1997).

To further explore this latter hypothesis, we administered the NMDA antagonist phencyclidine (PCP) to primates and measured ${ }^{11} \mathrm{C}$-raclopride binding with $\mathrm{PCP}$ alone and in the presence of increased GABAergic activity with GVG. The NMDA antagonist model of schizophrenia has surpassed previous dopaminergic theories in both clinical and basic science investigations (Javitt and Zukin, 1991). Administration of NMDA antagonists produces symptoms in healthy controls that closely mimic those found in schizophrenic patients (Krystal et al., 1994). Further, when stable schizophrenic patients are given ketamine, an NMDA antagonist and PCP analog, their symptoms are exacerbated and they experience similar clinical manifestations to their pre-medicated state (Lahti et al., 1995b; Lahti et al., 1995a). We recently demonstrated the sensitivity of ${ }^{11} \mathrm{C}$-raclopride binding to changes in human brain activity induced by ketamine (Smith et al., 1998), while simultaneously collecting clinical measures of psychosis. Our results indicated that acute administration of ketamine decreased ${ }^{11} \mathrm{C}$-raclopride binding, thus increasing synaptic dopamine activity while concurrently producing psychosis. Our investigation, and the strategy of using ${ }^{11} \mathrm{C}$-raclopride binding to measure glutamatergic induced changes in striatal dopamine, was later supported by Breier et al., who found decreased ${ }^{11} \mathrm{C}$-raclopride binding in healthy subjects after ketamine administration (Breier et al., 1998).

Figure 2 indicates the time activity of basal receptor occupancy by ${ }^{11} \mathrm{C}$-raclopride and subsequent receptor occupancy after $1.0 \mathrm{mg} / \mathrm{kg}$ PCP in both the striatum and cerebellum. It is clear by the difference in striatal receptor occupancy (circles), that PCP administration diminishes ${ }^{11} \mathrm{C}$-raclopride binding compared to baseline, indicative of increased competition by synaptic dopamine release secondary to PCP. Additionally, the difference in cerebellar $\mathrm{D}_{2}$ 
occupancy between pre- and post challenge is clearly minimal (triangles), justifying its use as a reference region in kinetic models.

We have since taken this strategy one step further and demonstrated that decreased ${ }^{11} \mathrm{C}$ raclopride binding subsequent to NMDA-antagonist administration can be successfully modulated with GABAergic pretreatment. In other words, increased dopaminergic activity by PCP administration was diminished by pretreatment with $\mathrm{GVG}$, as evidenced by restoration of ${ }^{11} \mathrm{C}$-raclopride binding to levels similar to the test/retest group (Schiffer et al., submitted). Table 3 provides the change in mean distribution volume ratio (DVR) from the baseline scan $\left({ }^{11} \mathrm{C}\right.$ raclopride alone) and the post-challenge scan $\left({ }^{11} \mathrm{C}\right.$-raclopride in the presence of treatment paradigms) indicated. Lower numbers indicate less ${ }^{11} \mathrm{C}$-raclopride binding and higher endogenous dopamine receptor occupancy, while higher numbers indicate more ${ }^{11} \mathrm{C}$-raclopride binding as a result of less competition from synaptic dopamine. Further, changes in striatal dopamine for one primate given PCP Alone and one given GVG prior to PCP pretreatment are presented in Figure 3. Here, it is clear that there is less ${ }^{11} \mathrm{C}$-raclopride binding in the primate given PCP, whereas in the animal pretreated with $\mathrm{GVG},{ }^{11} \mathrm{C}$-raclopride binding in the second scan is very similar to baseline.

This investigation demonstrated that it is possible to modulate glutamate-induced increases in dopamine with increased inhibitory GABA levels, and that this pharmacologic interaction can be measured with ${ }^{11} \mathrm{C}$-raclopride binding and PET. This study is supported by our dialysis investigations employing a similar paradigm by measuring changes in extracellular dopamine release after GVG pretreatment and a PCP challenge (Schiffer et al., submitted). Together, these investigations support the utility of GVG, in combination with neuroleptics, as a possible therapeutic treatment for schizophrenic psychoses. It has been demonstrated that GVG successfully ameliorates many of the extra-pyramidal side effects secondary to chronic neuroleptic treatment (Korsgaard et al., 1983; Thaker et al., 1983). Additionally, it has been demonstrated that patients receiving long-term neuroleptic therapy are more vulnerable to psychostimulant abuse (Roberts and Vickers, 1984; Roberts and Vickers, 1987; Brady et al., 1990), so the anti-addictive properties of GVG demonstrated here might prove additionally therapeutic in schizophrenic populations. Finally, combining GVG with neuroleptic therapy might enable clinicians to diminish the dose of both drugs necessary for therapeutic efficacy (Wassef et al., 1999). 


\section{Modulation of cholinergic activity studied with ${ }^{11} \mathrm{C}$-benztropine}

The function of the cholinergic system and its modulation by other systems may be critical to the pathophysiology of Alzheimer's disease and schizophrenia, and may provide insight into the manifestation of extrapyramidal side effects produced by antipsychotic treatment. An example of a relevant application of this approach is to study Alzheimer's disease. Alzheimer's disease has classically been characterized by a cortical cholinergic deficit (Bartus et al., 1982). The majority of drug trials have used therapeutic agents (e.g., cholinergic agonists and cholinesterase inhibitors) that were designed to directly reverse this deficiency. With few exceptions, these drugs have not been efficacious.

Further, a model for schizophrenia has been proposed that hinges on cholinergic/dopaminergic interactions. In this model, cholinergic hyperactivity is postulated as an adaptive response to presumed dopaminergic hyperactivity and is considered to be responsible for the negative symptoms of schizophrenia (Tandon and Greden, 1989). More recent investigations support the involvement of muscarinic receptors specifically, in the pathogenesis of schizophrenia (Crook et al., 2000). It has been difficult to tease out the contributions of the disease mechanism itself, or of the effects of neuroleptic medications on schizophrenic pathology. Side effects associated with neuroleptic treatment (tardive dyskenesia) are alleviated by treatment with anticholinergic drugs (Lewis, 1998). These investigations provided the clinical impetus for investigating the cholinergic system over other neurotransmitter systems.

Prior to addressing the usefulness of PET for investigating intrinsic interactions between $\mathrm{ACh}$ and DA, it was essential to develop a radiotracer specific for the cholinergic receptor. We chose benztropine for several reasons. First, it is a clinically prescribed synthetic anticholinergic drug frequently used in conjunction with neuroleptic medication in humans. Benztropine rapidly alleviates the extrapyramidal side effects commonly associated with dopaminergic $\mathrm{D}_{2}$ receptor blockade. Secondly, benztropine has a long biological half-life, which suggested it remained intact in the systemic circulation. Thirdly, it could be radiolabeled with carbon-11 in high specific activity $(0.75-2.0 \mathrm{Ci} / \mu \mathrm{mol})$. Recently, the ligands ${ }^{11} \mathrm{C}$-tropanyl benzilate and ${ }^{11} \mathrm{C}-\mathrm{N}$ methyl-4-piperidyl benzilate have been developed as radiotracers for the muscarinic receptor (Mulholland et al., 1992; Koeppe et al., 1992; Lee et al., 1991). The primary advantages of ${ }^{11} \mathrm{C}-$ benztropine over other muscarinic cholinergic ligands is that pharmacologic doses can be 
administered to humans, so that the extent of specific binding in the PET data, using the unlabeled compound, can be determined. Additionally, striatal DV values obtained with these other radiotracers $\left({ }^{11} \mathrm{C}\right.$-tropanyl benzilate and ${ }^{11} \mathrm{C}-\mathrm{N}$-methyl-4-piperidyl benzilate) are consistent with our ${ }^{11} \mathrm{C}$-benztropine results. It is important to note that benztropine has been shown to inhibit DA reuptake in the corpus striatum in vitro (Coyle and Snyder, 1969). In order to determine which component of the PET image of labeled benztropine was due to binding to the DA transporter, we pretreated animals with nomifensine $(2.0 \mathrm{mg} / \mathrm{kg})$, a potent DA transport blocker (Dewey et al., 1990b). Incorporation of labeled benztropine was not altered in any brain structure examined following nomifensine pretreatment. Subsequent studies were performed with ${ }^{11} \mathrm{C}$-benztropine and GBR-12909 and ${ }^{11} \mathrm{C}$-benztropine and cocaine in order to examine whether or not labeled benztropine was binding to the DA transporter in the striatum of the baboon brain. GBR-12909 was chosen as we have demonstrated that it decreases the striatal binding of labeled raclopride presumably due to its binding to the DA transporter. Cocaine was chosen for similar reasons. Systemic administration of either GBR-12909 or cocaine did not alter the binding of labeled benztropine in any brain region examined. These studies are consistent with the nomifensine data. Finally, unlabeled benztropine did not alter ${ }^{11} \mathrm{C}$-cocaine binding. It appears that the binding of ${ }^{11} \mathrm{C}$-benztropine to the DA transporter does not make a significant contribution to the PET image (Dewey et al., 1990b).

Cholinergic cells in the striatum only represent a small population of striatal neurons, but are able to modulate the excitability in this brain region due to their widespread axonal fields and high sensitivity to related neurotransmitter systems (Kincaid et al., 1998). Studies investigating in vivo and in vitro acetylcholine release have demonstrated that dopamine controls cholinergic transmission in a facilitory manner both directly and indirectly (Damsma et al., 1990). For a review of our studies with the cholinergic ligand, ${ }^{11} \mathrm{C}$-benztropine, please see Table 2.

\section{Dopaminergic modulation of acetylcholine}

Our initial studies of the cholinergic system as the outcome measure for choline/dopamine interactions explored the effects of decreased dopaminergic activity on ${ }^{11} \mathrm{C}$ benztropine binding. We first studied the effect of a dopamine antagonist on the binding of the ${ }^{11} \mathrm{C}$-benztropine in the baboon (Dewey et al., 1990a). Pretreatment with unlabeled NMSP, a potent dopaminergic antagonist, reduced ${ }^{11} \mathrm{C}$-benztropine binding in all brain regions, with the 
effects in the corpus striatum being greater than the cortex and thalamus, and very little binding found in the cerebellum.

Our data are consistent with a physiology where cholinergic interneurons are disinhibited from blockade of $\mathrm{D}_{2}$ afferents (Bymaster et al., 1986), producing increased acetylcholine release and subsequently decreased ${ }^{11} \mathrm{C}$-benztropine binding.

Here, we demonstrated decreasing dopaminergic activity with NMSP produced subsequent increases in acetylcholine levels, indexed by decreases in ${ }^{11}$ C-benztropine binding (Table 2).

\section{Serotonergic modulation of acetylcholine}

The modulatory role of serotonin on acetylcholine activity has been extensively documented (Giovannini et al., 1998)), and more recent theories propose serotonin stimulates acetylcholine release through increased dopaminergic activity in animals, consistent with our primate investigations (Ramirez et al., 1997). The dorsal and median raphe nuclei are the major sources of 5-HT in the CNS. $5-\mathrm{HT}_{2}$ receptors have been localized to cortical cholinergic nerve terminals as revealed by the loss of these receptors secondary to lesions of the nucleus basalis of Meynert (Quirion and Richard, 1985). Serotonergic enervation to the striatum is derived from the dorsal and medial raphe nuclei, which project to the striatum, pallidum, and substantia nigra (mainly the pars compacta). Serotonin has been shown to inhibit striatal ACh release (Euvrard $e t$ al., 1977); (Guyenet et al., 1977) and depletion of endogenous 5-HT increased the release of striatal ACh (Visi et al., 1981). Gillet and coworkers (Gillet et al., 1985) demonstrated that exogenously administered 5-HT, 5-HT agonists, or fluoxetine, an inhibitor of 5-HT uptake, reduced striatal ACh release, whereas methylsergide, a 5-HT agonist, increased ACh efflux in the caudal striatum (Jackson et al., 1988). However, Robinson (Robinson, 1983) found no effect of 5-HT on striatal ACh levels but instead reported an inhibition of Ach in cortex and hippocampus.

We examined the modulation of acetylcholine by serotonin by measuring the effect of the serotonin antagonist altanserin on the binding of ${ }^{11} \mathrm{C}$-benztropine in primates (Dewey et al., 1993a). Decreasing serotonin activity with altanserin led to a decrease of striatal benztropine binding of $\sim 30 \%$; which is consistent with profound regional increases in acetylcholine release. 
These results confirm data from other studies indicating serotonin exerts a predominantly inhibitory influence on cholinergic interneurons in the rat striatum (Visi et al., 1981).

In sum, decreasing serotonin activity with altanserin produced increases in synaptic acetylcholine levels, measured by decreases in ${ }^{11}$ C-benztropine binding.

\section{GABAergic modulation of acetylcholine}

Due to the large inhibitory capacity of the GABA system, many investigations have focused on the effects of GABAergic agents on acetylcholine release. The ventral pallidum receives direct input from ventral striatal regions that contain a large number of GABAergic interneurons (Heimer and Wilson, 1975). It is unresolved, however, whether this GABAergic input originates from these striatal GABAergic neurons or whether it arises from axons of other projection or GABAergic interneurons. Unlike the findings reported with 5-HT, studies with GABA and GABA mimetic drugs such as muscimol and SL 76002 have demonstrated the ability to increase striatal ACh content, the largest of which was observed in the rat striatum with smaller effects in the cortex, nucleus accumbens, olfactory tubercle, hippocampus, interpendicular nucleus, hypothalamus and brainstem (Scatton and Bartholini, 1980). GABAergic neuronal terminals make contact not only with cholinergic neurons (DeBoer and Westerink, 1994), but also with glutamatergic (Moratalla and Bowery, 1991) and dopaminergic neurons in the striatum (Bowery et al., 1990). Furthermore, striatal cholinergic neurons are regulated by glutamatergic and dopaminergic neurons, which are thought to form synapses on cholinergic neurons. It is thought that striatal GABAergic inhibition of dopaminergic or glutamatergic activity relieves the tonic inhibition or excitation of cholinergic neurons (Ikarashi et al., 1998; Moratalla and Bowery, 1991). A recent microdialysis study demonstrated that the GABAergic system appears to inhibit tonically the output of striatal acetylcholine via $\mathrm{GABA}_{\mathrm{A}}$ receptors, but not via $\mathrm{GABA}_{\mathrm{B}}$ receptors (DeBoer and Westerink, 1994). GVG provides an ideal mechanism for measuring the effects of increased endogenous GABA activity on the cholinergic system, as its effects are not mediated through any specific receptor system.

Investigating the effects of GVG on the regional binding of ${ }^{11} \mathrm{C}$-benztropine in the primate brain produced interesting results that supported the utility of PET as a measure of in vivo neurotransmitter activity (Dewey et al., 1993a). GVG produced a regionally specific decrease in ${ }^{11} \mathrm{C}$-benztropine binding. Striatal binding decreased $47 \%$ and cortical binding 
decreased $28 \%$, but no changes in either thalamic or cerebellar uptake were observed. These regional and quantitative changes are consistent with the aforementioned excitatory role of GABA in striatal and cortical acetylcholine release (Scatton and Bartholini, 1980).

Taken with our previous work using ${ }^{11} \mathrm{C}$-raclopride and GVG (Dewey et al., 1992b), this study represents the first demonstration with PET that a single drug (GVG), within the same time frame, can produce opposite effects in different neurotransmitter systems within the same animal. Specifically, GVG administration increased ${ }^{11} \mathrm{C}$-raclopride binding and decreased ${ }^{11} \mathrm{C}$ benztropine binding.

Increasing GABA activity with vigabatrin produced subsequent increases in cholinergic activity, measured by decreases in ${ }^{11}$ C-benztropine binding.

\section{SUMMARY}

These data support the use of PET not only to monitor changes in synaptic neurotransmitter concentrations, but also to assessing the multiple mechanisms of action of new and potentially useful centrally acting therapeutic drugs. These findings have implications for the pathophysiology and pharmacotherapy of disease states that have classically been defined as neurotransmitter specific in origin. Specifically, we can use this application of PET as a tool to determine whether the ability of a neurotransmitter to modulate the activity of another functionally linked neurotransmitter is involved in the disease process. By capitalizing on our knowledge concerning neurotransmitter interactions, this would have direct implications for treatment in that therapeutic efficacy could be achieved indirectly, rather than directly, altering neurotransmitter activity. Potential treatments could be developed for cholinergic, dopaminergic and serotonergic defect states. Furthermore, this information may be used to predict the potential side effects of pharmacologic treatment in psychiatric disorders.

Combined with an exhaustive literature supporting the fundamental principle that neurotransmitters interact in both functionally-specific and regionally specific neuroanatomical foci, it is becoming increasingly clear that new treatment strategies for brain disorders (including addictions to cocaine, nicotine, heroin, and methamphetamine) should be developed with a more global awareness of this fundamental and well-documented principle. While changes in individual neurotransmitter concentrations may indeed underlie the etiology of a specific disorder, it is likely that disease progression and symptom development are linked to 
compensatory or disease-induced changes in other neurotransmitters functionally linked to the original target. With this knowledge, we have been developing novel treatment strategies specifically designed to alter one or more neurotransmitters by targeting another. Our findings with nicotine, cocaine, methamphetamine, alcohol and GVG represent the potential utility of such a fundamental approach. 


\section{ACKNOWLEDGMENTS}

This research was carried out at Brookhaven National Laboratory under contract with the U.S. Department of Energy Office of Biological and Environmental Research (USDOE/OBER DE-AC02-98CH10886) and by the National Institutes of Mental Health (NIMH MH49165 and NIMH R2955155) and the National Institute on Drug Abuse (5RO-DA06278). 


\section{FOOTNOTES}

${ }^{1}$ Given a five-fold higher affinity than ${ }^{11} \mathrm{C}$-raclopride, our laboratory demonstrated in vivo sensitivity of ${ }^{18} \mathrm{~F}-\mathrm{NMSP}$ to dopamine in PET studies performed following $d$-amphetamine administration. These studies demonstrated that in vivo pharmacokinetic effects such as tissue clearance play an important role in radioligand sensitivity of high affinity radioligands to endogenous DA concentrations (Dewey et al., 1991; Logan et al., 1991).

${ }^{2}$ In primates, the accumbens cells blend with those of the anteroventral putamen and the ventral caudate, so that a distinct border of the accumbens is not evident (Heimer et al., 1991). Recently, Drevets et al, have demonstrated that any potential bias effects due to resolution of PET cameras was significantly smaller than the magnitude of the observed changes in ${ }^{11} \mathrm{C}$-raclopride binding after amphetamine administration, supporting the correlation between microdialysis studies of psychostimulant activity in the NAcc and PET studies of psychostimulants in primates (Drevets et al., 1999). 


\section{REFERENCES}

Arnfred T and Randrup A (1968) Acta pharmacol toxicol. Cholinergic mechanism in brain inhibiting amphetamine-induced stereotyped behavior., 26, 384-394.

Bartus RT, Dean RLd, Beer B and Lippa AS (1982) The cholinergic hypothesis of geriatric memory dysfunction. Science, 217, 408-14.

Bloom F, Costa E and Salmoiraghi GC (1965) Anesthesia and the responsiveness of individual neurons of the caudate nucleus of the cat to acetylcholine, norepinephrine and dopamine administered by microelectrophoresis. $J$ Pharmacology and experimental therapeutics, 50, 244-52.

Bowen DM, Allen SJ, Benton JS, Goodhardt MJ, Haan EA, Palmer AM, Sims NR, Smith CC, Spillane JA, Esiri MM, Neary D, Snowdon JS, Wilcock GK and Davison AN (1983) Biochemical assessment of serotonergic and cholinergic dysfunction and cerebral atrophy in Alzheimer's disease. $J$ Neurochem, 41, 266-72.

Bowery NG, Knott C, Moratalla R and Pratt GD (1990) GABAB receptors and their heterogeneity. Adv Biochem Psychopharmacol, 46, 127-39.

Brady K, Anton R, Ballenger JC, Lydiard RB, Adinoff B and Selander J (1990) Cocaine abuse among schizophrenic patients. Am J Psychiatry, 147, 1164-7.

Breier A, Adler CM, Weisenfeld N, Su TP, Elman I, Picken L, Malhotra AK and Pickar D (1998) Effects of NMDA antagonism on striatal dopamine release in healthy subjects: application of a novel PET approach. Synapse, 29, 142-7.

Breier A, Su TP, Saunders R, Carson RE, Kolachana BS, de Bartolomeis A, Weinberger DR, Weisenfeld N, Malhotra AK, Eckelman WC and Pickar D (1997) Schizophrenia is associated with elevated amphetamine-induced synaptic dopamine concentrations: evidence from a novel positron emission tomography method. Proc Natl Acad Sci USA, 94, 2569-74.

Bunney BS and Aghajanian GK (1976) Dopaminergic infllence in the basal ganglia: evidence for striatonigral feedback regulation. Res Publ Assoc Res Nerv Ment Dis, 55, 249-67.

Burns HD, Hamill TG, Eng W, Francis B, Fioravanti C and Gibson R (1999) Positron emission tomography neuroreceptor imaging as a tool in drug discovery, research and development. current opinion in chemical biology, 3, 388-394. 
Bymaster FP, Reid LR, Nichols CL, Kornfeld EC and Wong DT (1986) Elevation of acetylcholine levels in striatum of rat brain by LY163502, trans-(-)-5,5a,6,7,8,9a,10octahydro-6-propylpyrimido less than 4,5-g greater than quinolin-2-amine dihydrochloride, a potent and stereospecific dopamine (D2) agonist. Life Sci, 38, 317-22.

Cortes R, Probst A and Palacios JM (1987) Quantitative light microscopic autoradiographic localization of cholinergic muscarinic receptors in the human brain: forebrain. Neuroscience, 20, 65-107.

Costall B and Olley JE (1971) Cholinergic and neuroleptic induced catalepsy: modification by lesions in the caudate putamen. Neuropharmacology, 10, 297-306.

Coyle JT and Snyder SH (1969) Antiparkinsonian drugs: inhibition of dopamine uptake in the corpus striatum as a possible mechanism of action. Science, 166, 899-901.

Crook JM, Tomaskovic-Crook E, Copolov DL and Dean B (2000) Decreased muscarinic receptor binding in subjects with schizophrenia: A study of the human hippocampal formation. Biol Psychiatry, 48, 381-388.

Crow TJ, Cross AJ, Cooper SJ, Deakin JF, Ferrier IN, Johnson JA, Joseph MH, Owen F, Poulter M, Lofthouse R and al e (1984) Neurotransmitter receptors and monoamine metabolites in the brains of patients with Alzheimer-type dementia and depression, and suicides. Neuropharmacology, 23, 1561-9.

Damsma G, de Boer P, Westerink BH and Fibiger HC (1990) Dopaminergic regulation of striatal cholinergic interneurons: an in vivo microdialysis study. Naunyn Schmiedebergs Arch Pharmacol, 342, 523-7.

Davies P and Verth AH (1977) Regional distribution of muscarinic acetylcholine receptor in normal and Alzheimer's-type dementia brains. Brain Res, 138, 385-92.

DeBoer P and Westerink BH (1994) GABAergic modulation of striatal cholinergic interneurons: an in vivo microdialysis study. $J$ Neurochem, 62, 70-5.

DeFeudis FV (1984) gamma-Aminobutyric acid-ergic analgesia: implications for gammaaminobutyric acid-ergic therapy for drug addictions. Drug Alcohol Depend, 14, 101-11.

Dewey SL, Brodie JD, Fowler JS, MacGregor RR, Schlyer DJ, King PT, Alexoff DL, Volkow ND, Shiue CY, Wolf AP and et al. (1990a) Positron emission tomography (PET) studies of dopaminergic/cholinergic interactions in the baboon brain. Synapse, 6, 321-7. 
Dewey SL, Brodie JD, Gerasimov M, Horan B, Gardner EL and Ashby CRJ (1999) A pharmacologic strategy for the treatment of nicotine addiction. Synapse, 31, 76-86.

Dewey SL, Chaurasia CS, Chen CE, Volkow ND, Clarkson FA, Porter SP, Straughter-Moore RM, Alexoff DL, Tedeschi D, Russo NB, Fowler JS and Brodie JD (1997) GABAergic attenuation of cocaine-induced dopamine release and locomotor activity. Synapse, 25, 393-8.

Dewey SL, Logan J, Wolf AP, Brodie JD, Angrist B, Fowler JS and Volkow ND (1991) Amphetamine induced decreases in (18F)-N-methylspiroperidol binding in the baboon brain using positron emission tomography (PET). Synapse, 7, 324-7.

Dewey SL, MacGregor RR, Brodie JD, Bendriem B, King PT, Volkow ND, Schlyer DJ, Fowler JS, Wolf AP, Gatley SJ and al e (1990b) Mapping muscarinic receptors in human and baboon brain using [N-11C-methyl]-benztropine. Synapse, 5, 213-23.

Dewey SL, Morgan AE, Ashby CR, Jr., Horan B, Kushner SA, Logan J, Volkow ND, Fowler JS, Gardner EL and Brodie JD (1998) A novel strategy for the treatment of cocaine addiction. Synapse, 30, 119-29.

Dewey SL, Smith GS, Logan J, Alexoff D, Ding YS, King P, Pappas N, Brodie JD and Ashby CRJ (1995) Serotonergic modulation of striatal dopamine measured with positron emission tomography (PET) and in vivo microdialysis. $J$ Neurosci, 15, 821-9.

Dewey SL, Smith GS, Logan J and Brodie JD (1993a) Modulation of central cholinergic activity by GABA and serotonin: PET studies with 11C-benztropine in primates. Neuropsychopharmacology, 8, 371-6.

Dewey SL, Smith GS, Logan J, Brodie JD, Fowler JS' and Wolf AP (1993b) Striatal binding of the PET ligand $11 \mathrm{C}$-raclopride is altered by drugs that modify synaptic dopamine levels. Synapse, 13, 350-6.

Dewey SL, Smith GS, Logan J, Brodie JD, Simkowitz P, MacGregor RR, Fowler JS, Volkow ND and Wolf AP (1993c) Effects of central cholinergic blockade on striatal dopamine release measured with positron emission tomography in normal human subjects. Proc Natl Acad Sci USA, 90, 11816-20.

Dewey SL, Smith GS, Logan J, Brodie JD, Yu DW, Ferrieri RA, King PT, MacGregor RR, Martin TP, Wolf AP and al e (1992a) GABAergic inhibition of endogenous dopamine 
release measured in vivo with 11C-raclopride and positron emission tomography. $J$ Neurosci, 12, 3773-80.

Dewey SL, Smith GS, Logan J, Brodie JD, Yu DW, Ferrieri RA, King PT, MacGregor RR, Martin TP, Wolf AP and et al. (1992b) GABAergic inhibition of endogenous dopamine release measured in vivo with $11 \mathrm{C}$-raclopride and positron emission tomography. $J$ Neurosci, 12, 3773-80.

Dewey SL, Volkow ND, Logan J, MacGregor RR, Fowler JS, Schlyer DJ and Bendriem B (1990c) Age-related decreases in muscarinic cholinergic receptor binding in the human brain measured with positron emission tomography (PET). J Neurosci Res, 27, 569-75.

Dewey SL, Wolf AP, Fowler JS, Brodie JD, Shiue C-Y, Alavi A, Hiesiger E, Schlyer D, Volkow N, Raulli R and Christman D (1988) The effects of central cholinergic blockage on [18F]-N-Methylspiroperidol binding in the human brain using PET. XVIth C.I.N.P. Congress, Munich, West Germany, August 15-19, 1988.

Di Chiara G, Morelli M, Acquas E and Carboni E (1992) Functions of dopamine in the extrapyramidal and limbic systems. Clues for the mechanism of drug actions. Arzneimittelforschung, 42, 231-7.

Di Chiara G, Tanda G, Frau $\dot{R}$ and Carboni E (1993) On the preferential release of dopamine in the nucleus accumbens by amphetamine: further evidence obtained by vertically implanted concentric dialysis probes. Psychopharmacology, 112, 398-402.

Ding YS, Fowler JS, Volkow ND, Logan J, Gatley SJ and Sugano Y (1995) Carbon-11-d-threomethylphenidate binding to dopamine transporter in baboon brain. J Nucl Med, 36, 2298305.

Drevets WC, Price JC, Kupfer DJ, Kinahan PE, Lopresti B, Holt D and Mathis C (1999) PET measures of amphetamine-induced dopamine release in ventral versus dorsal striatum. Neuropsychopharmacology, 21, 694-709.

Egan MF and Weinberger DR (1997) Neurobiology of schizophrenia. Curr Opin Neurobiol, 7, 701-7.

Ehlert FJ, Roeske WR and Yamamura HI (1981) Striatal muscarinic receptors: regulation by dopaminergic agonists. Life Sci, 28, 2441-8.

Euvrard C, Javoy F, Herbet A and Glowinski J (1977) Effect of quipazine, a 5-HT like drug, on striatal cholinergic interneurons. Eur J Pharmacol, 41, 281-289. 
Farde L, Wiessel F, Hall H, Halldin C, Stone-Elander S and Sedvall CG (1987) No D2 receptor increase in PET study of schizophrenia. Arch Gen Psychiatry, 44, 671-72.

Fibiger HC (1982) The organization and some projections of cholinergic neurons of the mammalian forebrain. Brain Res, 257, 327-88.

Fowler JS, Volkow ND, Wang GJ, Ding YS and Dewey SL (1999) PET and drug research and development. $J$ Nucl Med, 40, 1154-63.

Frey K, Koeppe R, Mulholland G and Kuhl D (1990) Quantification of regional cerebral muscarinic receptors in human brain with the use of [C-11]tropanyl benzilate and Positron Emission Tomography. J Nucl Med, 31, 885.

Frey KA, Koeppe RA, Kilbourn MR, Vander Borght TM, Albin RL, Gilman S and Kuhl DE (1996) Presynaptic monoaminergic vesicles in Parkinson's disease and normal aging. Ann Neurol, 40, 873-84.

Gerasimov MR, Ashby CR, Gardner EL, Mills MJ, Brodie JD and Dewey SL (1999) Gammavinyl GABA inhibits methamphetamine, heroin, or ethanol- induced increases in nucleus accumbens dopamine. Synapse, 34, 11-19.

Gillet G, Ammor S and Fillion G (1985) Serotonin inhibits acetylcholine release from rat striatum slices: evidence for a presynaptic receptor-mediated effect. $J$ Neurochem, 45, 1687-91.

Ginovart N, Lundin A, Farde L, Halldin C, Backman L, Swahn CG, Pauli S and Sedvall G (1997) PET study of the pre- and post-synaptic dopaminergic markers for the neurodegenerative process in Huntington's disease. Brain, 120 ( Pt 3), 503-14.

Giovannini MG, Ceccarelli I, Molinari B, Cecchi M, Goldfarb J and Blandina P (1998) Serotonergic modulation of acetylcholine release from cortex of freely moving rats. $J$ Pharmacol Exp Ther, 285, 1219-25.

Guyenet P, Euvrard C, Javoy F, Herbet A and Glowinski J (1977) Regional differences in the sensitivity of cholinergic neurons to dopaminergic drugs and quipazine in the rat striatum. Brain Res, 136, 487-500.

Heimer L and Wilson RD (1975) In Golgi Centennial Symposium Proceeding(Ed, Santini, M.) Raven Press, New York, pp. 177-193.

Heimer L, Zahm DS, Churchill L, Kalivas PW and Wohltmann C (1991) Specificity in the projection patterns of accumbal core and shell in the rat. Neuroscience, 41, 89-125. 
Hietala J, Kuoppamaki M, Nagren K, Lehikoinen P and Syvalahti E (1997) Effects of lorazepam administration on striatal dopamine D2 receptor binding characteristics in man--a positron emission tomography study. Psychopharmacology, 132, 361-5.

Ikarashi Y, Yuzurihara M, Takahashi A, Ishimaru H, Shiobara T and Maruyama Y (1998) Direct regulation of acetylcholine release by $\mathrm{N}$-methyl-D-aspartic acid receptors in rat striatum. Brain Res, 795, 215-20.

Jackson DM, Bruno JP and Stachowiak MK (1988) Inhibition of striatal acetylcholine release by endogenous serotonin. Brain Res, 457, 259-266.

Javitt DC and Zukin SR (1991) Recent advances in the phencyclidine model of schizophrenia. Am J Psychiatry, 148, 1301-8.

Joyce JN (1993) The dopamine hypothesis of schizophrenia: limbic interactions with serotonin and norepinephrine. Psychopharmacology, 112, S16-34.

Joyce JN, Shane A, Lexow N, Winokur A, Casanova MF and Kleinman JE (1993) Serotonin uptake sites and serotonin receptors are altered in the limbic system of schizophrenics [see comments]. Neuropsychopharmacology, 8, 315-36.

Kapur S and Remington G (1996) Serotonin-dopamine interaction and its relevance to schizophrenia. Am J Psychiatry, 153, 466-76.

Keverne EB (1999) GABA-ergic neurons and the neurobiology of schizophrenia and other psychoses. Brain Res Bull, 48, 467-73.

Kincaid AE, Zheng $\mathrm{T}$ and Wilson CJ (1998) Connectivity and convergence of single corticostriatal axons. J Neurosci, 18, 4722-31.

Koeppe R, Frey K, Zubleta J, Fessler J, Mulholland G, Kilbourn M, Mangner T and Kuhl D (1992) Tracer kinetic analysis of C-11-N-methyl-4piperidyl benzilate binding to muscarinic cholinergic receptors. $J$ Nucl Med, 33, 882.

Koeppe R, Holtoff V, Frey K, Kilbourn M, Paradise A and Kuhl D (1991) Analysis of [C11]Flumazenil kinetics: validation of model for differentiation between ligand delivery and binding. $J$ Nucl Med, 32, 980.

Koob GF (2000) Neurobiology of addiction. Toward the development of new therapies. Ann NY Acad Sci, 909, 170-85.

Korsgaard S, Casey DE and Gerlach J (1983) Effect of gamma-vinyl GABA in tardive dyskinesia. Psychiatry Res, 8, 261-9. 
Krystal JH, Karper LP, Seibyl JP, Freeman GK, Delaney R, Bremner JD, Heninger GR, Bowers MBJ and Charney DS (1994) Subanesthetic effects of the noncompetitive NMDA antagonist, ketamine, in humans. Psychotomimetic, perceptual, cognitive, and neuroendocrine responses. Arch Gen Psychiatry, 51, 199-214.

Kushner SA, Dewey SL and Kornetsky C (1997) Gamma-vinyl GABA attenuates cocaineinduced lowering of brain stimulation reward thresholds. Psychopharmacology, 133, 3838.

Kushner SA, Dewey SL and Kornetsky C (1999) The irreversible gamma-aminobutyric acid (GABA) transaminase inhibitor gamma-vinyl-GABA blocks cocaine self-administration in rats. J Pharmacol Exp Ther, 290, 797-802.

Lahti AC, Holcomb HH, Medoff DR and Tamminga CA (1995a) Ketamine activates psychosis and alters limbic blood flow in schizophrenia. Neuroreport, 6, 869-72.

Lahti AC, Koffel B, LaPorte D and Tamminga CA (1995b) Subanesthetic doses of ketamine stimulate psychosis in schizophrenia. Neuropsychopharmacology, 13, 9-19.

Lee K, Frey K, Koeppe R, Buck A, Mulholland G, Foster N and Kuhl D (1991) Quantification of muscarinic cholinergic receptors in aging and Alzheimer's disease. $J$ Nucl Med, 5, 942.

Lehmann J and Langer SZ (1982) Muscarinic receptors on dopamine terminals in the cat caudate nucleus: neuromodulation of $[3 \mathrm{H}]$ dopamine release in vitro by endogenous acetylcholine. Brain Res, 248, 61-9.

Lewis R (1998) Typical and atypical antipsychotics in adolescent schizophrenia: efficacy, tolerability, and differential sensitivity to extrapyramidal symptoms. Canadian Journal of Psychiatry. Revue Canadienne de Psychiatrie, 43, 596-604.

Logan J, Dewey SL and Wolf AP (1992) Effects of endogenous dopamine on measures of 18F$\mathrm{N}$-methylspiroperidol binding in the basal ganglia: comparison of simulations and experimental results from PET studies in baboons. Synapse, 9, 195-207.

Logan J, Dewey SL, Wolf AP, Fowler JS, Brodie JD, Angrist B, Volkow ND and Gatley SJ (1991) Effects of endogenous dopamine on measures of [18F]N-methylspiroperidol binding in the basal ganglia: comparison of simulations and experimental results from PET studies in baboons. Synapse, 9, 195-207.

Logan J, Fowler JS, Volkow ND, Wolf AP, Dewey SL, Schlyer DJ, MacGregor RR, Hitzemann R, Bendriem B, Gatley SJ and et al. (1990) Graphical analysis of reversible radioligand 
binding from time-activity measurements applied to [N-11C-methyl]-(-)-cocaine PET studies in human subjects. J Cereb Blood Flow Metab, 10, 740-7.

Logan J, Volkow ND, Fowler JS, Wang GJ, Fischman MW, Foltin RW, Abumrad NN, Vitkun S, Gatley SJ, Pappas N, Hitzemann R and Shea CE (1997) Concentration and occupancy of dopamine transporters in cocaine abusers with [11C]cocaine and PET. Synapse, 27, 34756.

McBride WJ, Murphy JM and Ikemoto S (1999) Localization of brain reinforcement mechanisms: intracranial self- administration and intracranial place-conditioning studies. Behav Brain Res, 101, 129-52.

Meltzer HY and Stahl SM (1976) The dopamine hypothesis of schizophrenia: a review. Schizophr Bull, 2, 19-76.

Meyer P, Bohnen NI, Minoshima S, Koeppe RA, Wernette K, Kilbourn MR, Kuhl DE, Frey KA and Albin RL (1999) Striatal presynaptic monoaminergic vesicles are not increased in Tourette's syndrome. Neurology, 53, 371-4.

Middlemiss DN, Palmer AM, Edel N and Bowen DM (1986) Binding of the novel serotonin agonist 8-hydroxy-2-(di-n-propylamino) tetralin in normal and Alzheimer brain. $J$ Neurochem, 46, 993-6.

Moratalla R and Bowery NG (1991) Chronic lesion of corticostriatal fibers reduces GABAB but not GABAA binding in rat caudate putamen: an autoradiographic study. Neurochem Res, 16, 309-15.

Mulholland G, Otto C, Jewett D, Kilbourn M, Koeppe R, Sherman P, Petry N, Carey J, Atkinson E, Archer S, Frey K and Kuhl D (1992) Synthesis, rodent biodistribution dosimetry, metabolism and monkey images of Carbon-11-labeled (+)-2 alpha-tropanyl benzilate: a central muscarinic receptor imaging agent. $J$ Nucl Med, 33, 423-430.

Olney JW and Farber NB (1995) Glutamate receptor dysfunction and schizophrenia. Arch Gen Psychiatry, 52, 998-1007.

Pucilowski O and Kostowski W (1983) Aggressive behaviour and the central serotonergic systems. Behav Brain Res, 9, 33-48.

Quirion R and Richard J (1985) Differential effects of selective lesions of cholinergic and dopaminergic neurons on serotonin-type 1 receptors in rat brain. Synapse, 1, 124-130. 
Ramirez MJ, Cenarruzabeitia E, Lasheras B and Del Rio J (1997) 5-HT2 receptor regulation of. acetylcholine release induced by dopaminergic stimulation in rat striatal slices. Brain Res, 757, 17-23.

Reynolds GP, Arnold L, Rossor MN, Iversen LL, Mountjoy CQ and Roth M (1984) Reduced binding of $[3 \mathrm{H}]$ ketanserin to cortical 5-ht2 receptors in senile dementia of the Alzheimer type. Neurosci Lett, 44, 47-51.

Robbins TW, Cador M, Taylor JR and Everitt BJ (1989) Limbic-striatal interactions in rewardrelated processes. Neurosci Biobehav Rev, 13, 155-62.

Roberts DC and Vickers G (1984) Atypical neuroleptics increase self-administration of cocaine: an evaluation of a behavioural screen for antipsychotic activity. Psychopharmacology, 82, 135-9.

Roberts DC and Vickers G (1987) The effect of haloperidol on cocaine self-administration is augmented with repeated administrations. Psychopharmacology, 93, 526-8.

Robinson SE (1983) Effect of specific serotonergic lesions on cholinergic neurons in the hippocampus, cortex and striatum. Life Sci, 32, 345-53.

Scatton B and Bartholini G (1980) Modulation by GABA of cholinergic transmission in the striatum. Brain Res, 183, 211-6.

Schiffer WK, Gerasimov MR, Bermel RA, Brodie JD and Dewey SL (2000) Stereoselective inhibition of dopaminergic activity by gamma vinyl-GABA following a nicotine or cocaine challenge: a PET/microdialysis study. Life Sci, 66, PL169-73.

Seeman P, Niznik HB and Guan HC (1990) Elevation of dopamine D2 receptors in schizophrenia is underestimated by radioactive raclopride [letter]. Arch Gen Psychiatry, 47, 1170-2.

Smith GS, Dewey SL, Brodie JD, Logan J, Vitkun SA, Simkowitz P, Schloesser R, Alexoff DA, Hurley A, Cooper T and Volkow ND (1997) Serotonergic modulation of dopamine measured with $[11 \mathrm{C}]$ raclopride and PET in normal human subjects. Am J Psychiatry, $154,490-6$.

Smith GS, Schloesser R, Brodie JD, Dewey SL, Logan J, Vitkun SA, Simkowitz P, Hurley A, Cooper T, Volkow ND and Cancro R (1998) Glutamate modulation of dopamine measured in vivo with positron emission tomography (PET) and 11C-raclopride in normal human subjects. Neuropsychopharmacology, 18, 18-25. 
Stanley M and Mann JJ (1984) Suicide and serotonin receptors. Lancet, 1, 349.

Tandon R and Greden JF (1989) Cholinergic hyperactivity and negative schizophrenic symptoms. A model of cholinergic/dopaminergic interactions in schizophrenia. Arch Gen Psychiatry, 46, 745-53.

Thaker GK, Hare TA and Tamminga CA (1983) GABA system: clinical research and treatment of tardive dyskinesia. Mod Probl Pharmacopsychiatry, 21, 155-67.

Tiihonen J, Kuoppamaki M, Nagren K, Bergman J, Eronen E, Syvalahti E and Hietala J (1996) Serotonergic modulation of striatal D2 dopamine receptor binding in humans measured with positron emission tomography. Psychopharmacology, 126, 277-80.

Tsukada H, Nishiyama S, Kakiuchi T, Ohba H, Sato K and Harada N (1999) Is synaptic dopamine concentration the exclusive factor which alters the in vivo binding of [11C]raclopride?: PET studies combined with microdialysis in conscious monkeys. Brain Res, 841, 160-9.

Tune LE, Wong DF, Pearlson G, Strauss M, Young T, Shaya EK, Dannals RF, Wilson AA, Ravert HT, Sapp J and al e (1993) Dopamine D2 receptor density estimates in schizophrenia: a positron emission tomography study with $11 \mathrm{C}-\mathrm{N}$-methylspiperone. Psychiatry Res, 49, 219-37.

Visi ES, Harsing LGJ and Zsilla G (1981) Evidence of the modulatory role of serotonin in acetylcholine release from striatal interneurons. Brain Res, 212, 89-99.

Volkow ND, Fowler JS and Wang GJ (1999) Imaging studies on the role of dopamine in cocaine reinforcement and addiction in humans. J Psychopharmacol, 13, 337-45.

Vollenweider FX, Vontobel P, Hell D and Leenders KL (1999) 5-HT modulation of dopamine release in basal ganglia in psilocybin-induced psychosis in man--a PET study with [11C]raclopride. Neuropsychopharmacology, 20, 424-33.

Wassef AA, Dott SG, Harris A, Brown A, O'Boyle M, Meyer WJr and Rose RM (1999) Critical review of GABA-ergic drugs in the treatment of schizophrenia. J Clin Psychopharmacol, $19,222-32$.

Weinberger DR (1997) The biological basis of schizophrenia: new directions. J Clin Psychiatry, 58 Suppl 10, 22-7. 
Wesemann W, Weiner N, Rotsch M and Schulz E (1983) Serotonin binding in rat brain: circadian rhythm and effect of sleep deprivation. Journal of Neural Transmission. Supplementum, 18, 287-94.

Wong DF, Wagner HNJ, Tune LE, Dannals RF, Pearlson GD, Links JM, Tamminga CA, Broussolle EP, Ravert HT, Wilson AA and al e (1986) Positron emission tomography reveals elevated D2 dopamine receptors in drug-naive schizophrenics [published erratum appears in Science 1987 Feb 6;235(4789):623]. Science, 234, 1558-63.

Xi ZX and Stein EA (2000) Increased mesolimbic GABA concentration blocks heroin selfadministration in the rat. J Pharmacol Exp Ther, 294, 613-9.

Zazpe A, Artaiz I and Del Rio J (1994) Role of 5-HT3 receptors in basal and K(+)-evoked dopamine release from rat olfactory tubercle and striatal slices. $\mathrm{Br} J$ Pharmacol, 113, 968-72. 


\begin{tabular}{|c|c|c|c|c|c|}
\hline $\begin{array}{l}\text { Neurotransmitter } \\
\text { System }\end{array}$ & Radioligand & $\begin{array}{c}\text { Drug } \\
\text { Challenge }\end{array}$ & $\begin{array}{c}\text { Challenge } \\
\text { Effect }\end{array}$ & $\begin{array}{c}\text { Radioligand } \\
\text { Response }\end{array}$ & $\begin{array}{c}\text { Dopamine } \\
\text { Activity }\end{array}$ \\
\hline Dopamine & ${ }^{11} \mathrm{C}$-raclopride & $\begin{array}{l}\text { cocaine, } \\
\text { amphetamine }\end{array}$ & 仓 DA & I & 仓 \\
\hline Acetylcholine & ${ }^{18} \mathrm{~F}-\mathrm{NMSP}$ & $\begin{array}{l}\text { benztropine, } \\
\text { scopolamine }\end{array}$ & 仓 $\mathrm{ACh}$ & $\Omega$ & 仓 \\
\hline \multirow[t]{2}{*}{ Serotonin } & \multirow[t]{2}{*}{${ }^{11} \mathrm{C}$-raclopride } & \multirow{2}{*}{$\begin{array}{l}\text { altanserin } \\
\text { citalopram }\end{array}$} & 』5-HT & $\sqrt{2}$ & $\hat{\imath}$ \\
\hline & & & 仓 5-HT & 仓 & П \\
\hline \multirow[t]{2}{*}{ GABA } & \multirow[t]{2}{*}{${ }^{11} \mathrm{C}$-raclopride } & \multirow{2}{*}{$\begin{array}{l}\text { vigabatrin } \\
\text { lorazepam }\end{array}$} & 仓ि GABA & 仓 & $\Omega$ \\
\hline & & & 仓 $\mathrm{GABA}$ & 仓े & 诮 \\
\hline $\begin{array}{c}\text { GABA } \\
\text { dopamine }\end{array}$ & ${ }^{11} \mathrm{C}$-raclopride & $\begin{array}{l}\text { GVG + } \\
\text { cocaine }\end{array}$ & $\begin{array}{c}\text { 仓ि } \mathrm{GABA}, \\
\text { 仓 } \mathrm{DA}\end{array}$ & No change & No change \\
\hline Glutamate & ${ }^{11} \mathrm{C}$-raclopride & Phencyclidine & 仓 Glu & $\sqrt{3}$ & 仓 \\
\hline $\begin{array}{l}\text { Glutamate/ } \\
\text { dopamine }\end{array}$ & ${ }^{11} \mathrm{C}$-raclopride & $\begin{array}{c}\mathrm{GVG}+ \\
\text { phencyclidine }\end{array}$ & $\begin{array}{c}\text { î GABA, } \\
\text { î Glu }\end{array}$ & No change & No change \\
\hline
\end{tabular}




\begin{tabular}{|c|c|c|c|c|c|}
\hline $\begin{array}{l}\text { Neurotransmitter } \\
\text { System }\end{array}$ & Radioligand & $\begin{array}{c}\text { Drug } \\
\text { Challenge }\end{array}$ & $\begin{array}{c}\text { Challenge } \\
\text { Effect }\end{array}$ & $\begin{array}{l}\text { Radioligand } \\
\text { Response }\end{array}$ & $\begin{array}{c}\text { Cholinergic } \\
\text { Activity }\end{array}$ \\
\hline Dopamine & ${ }^{11} \mathrm{C}$-benztropine & NMSP & I DA & I & 仓 \\
\hline Serotonin & ${ }^{11} \mathrm{C}$-benztropine & altanserin & \& $5-\mathrm{HT}$ & $\sqrt{3}$ & 仓 \\
\hline GABA & ${ }^{11} \mathrm{C}$-benztropine & vigabatrin & 仓 $\mathrm{GABA}$ & ת & 仓 \\
\hline
\end{tabular}


Table 3. Change in mean Distribution Volume Ratio (DVR) from baseline scan to post-challenge scan

\begin{tabular}{|l|c|}
\hline \multicolumn{1}{|c|}{ Group } & $\begin{array}{c}\text { \% Change in } \\
\text { Mean DVR }\end{array}$ \\
\hline T/RT & $7 \pm 1.2$ \\
\hline GVG Alone & $18.8 \pm 3.2$ \\
\hline PCP Alone & $-33 \pm 5.31$ \\
\hline GVG + PCP & $12 \pm 8.42$ \\
\hline
\end{tabular}


Figure 1. Radioactivity distribution of ${ }^{11} \mathrm{C}$-raclopride (a) afte nicotine alone $(0.3 \mathrm{mg} / \mathrm{kg})$ and (b) after $S(+)-G V$ pretreatment $(150 \mathrm{mg} / \mathrm{kg})$ prior to the same nicotin challenge.
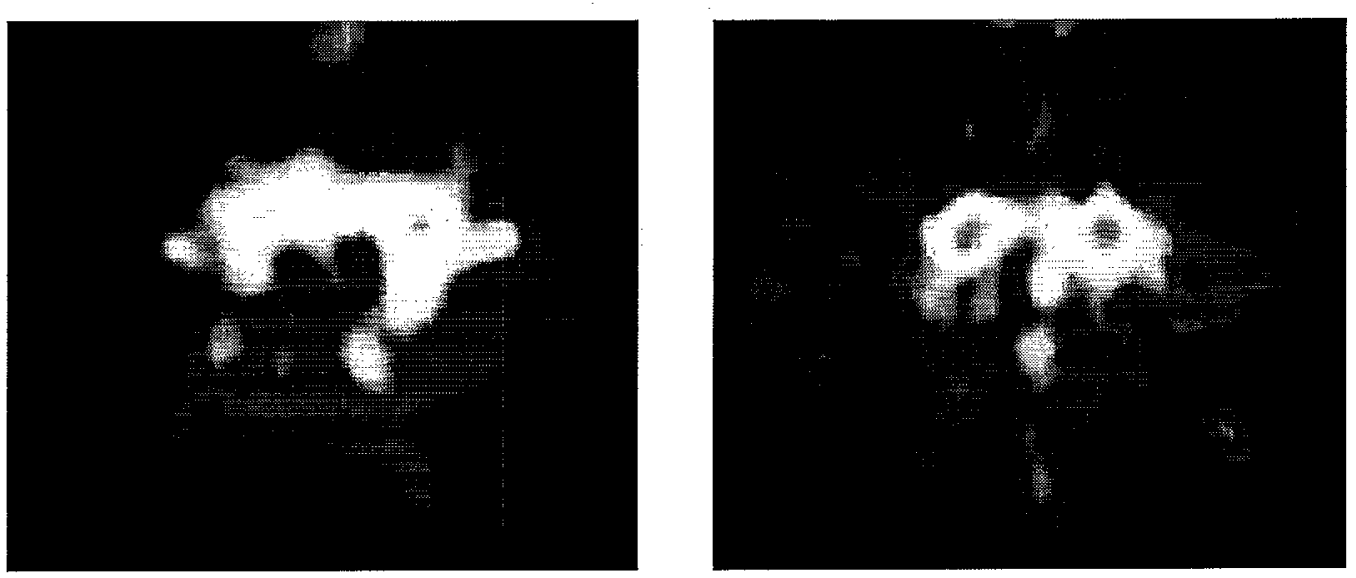
Figure 2. Time activity curve from a baseline ${ }^{11} \mathrm{C}$-raclopride scan (filled) and after PCP administration (open)




Figure 3. Logan plots of the striatal distribution volume from a non-human primate given PCP Alone (a) or an animal pretreated with GVG and given a PCP Challenge (b).

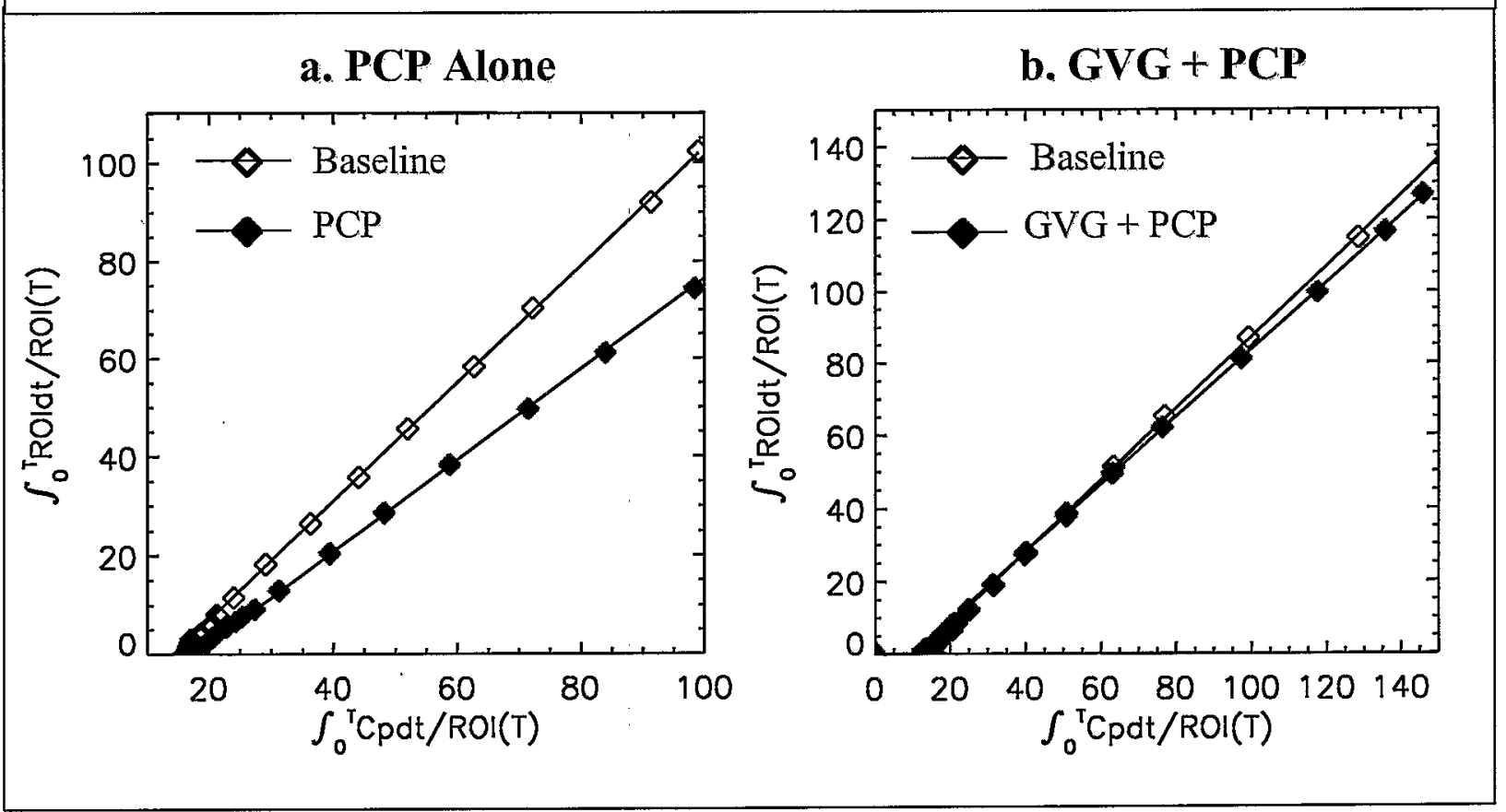




\section{Figure Captions}

Figure 1. Radioactivity distribution of ${ }^{11} \mathrm{C}$-raclopride in the papio anubis brain before and after nicotine alone and in the presence of GVG.

Figure 2. Time-activity data from striatum and cerebellum ROIs for papio anubis primates given a PCP challenge $(1.0 \mathrm{mg} / \mathrm{kg})$ prior to the second ${ }^{11} \mathrm{C}$-raclopride scan. Points on the graph are calculated for the midpoint of the scan times, represented by T. All points are corrected for the presence of labeled raclopride metabolites.

Figure 3. Graphical analysis of the time activity data from striatal ROIs in (a) one primate given a PCP challenge and (b) a primate pretreated with GVG followed by a PCP challenge. $\mathrm{ROI}(\mathrm{T})$ refers to radioactivity in the striatum at time $T . \mathrm{C}_{\mathrm{p}}(\mathrm{t})$ is the plasma radioactivity corrected for metabolites. 


\section{Keywords}

neurotransmitter interactions

dynamic brain scan

dopamine

acetylcholine

serotonin

GABA

schizophrenia

addiction 